\title{
Pengelolaan Bumdes Hanjak Maju Dalam Berkontribusi Pada Pendapatan Asli Desa di Desa Hanjak Maju Kecamatan Kahayan Hilir Kabupaten Pulang Pisau
}

\author{
Management of BUMD Hanjak Maju in contribution to the original income of the village in \\ Hanjak Maju, Kahayan Hilir District Pulang Pisau District
}

Irwani $^{1}$

Bahriannor ${ }^{2}$

1,2Dosen Program Studi

Administrasi Negara, Fisip.

Universitas Muhammadiyah

Palangkaraya.

*email:

nusaindah02I@gmail.com

\section{Kata Kunci:}

Badan Usaha Milik Desa

potensi desa

unit usaha TBS

\section{Keywords:}

Village-Owned Enterprises

village potential

TBS business unit

\begin{abstract}
Abstrak
Badan Usaha Milik Desa (BUMDes) adalah lembaga usaha desa yang dikelola oleh masyarakat dan pemerintah desa dalam upaya memperkuat perekonomian desa dan dibentuk berdasarkan kebutuhan dan potensi desa. Suatu Penelitan Kualitatif dilaksanakan untuk mengetahui bagaimana pengelolaan BUMdes Hanjak Maju dalam berkontribusi pada pendapatan asli desa di desa Hanjak Maju Kecamatan Kahayan Hilir Kabupaten Pulang Pisau. BUMDes Hanjak Maju memiliki unit usaha TBS kelapa sawit, gas $3 \mathrm{~kg}$ maupun pupuk. Jumlah Penerimaan PADes Hanjak Maju dengan rata-rata produksi TBS per bulan sebesar 100 Ton maka dalam setahun total produksi TBS Desa Hanjak Maju mencapai I.200 Ton. Upaya memperkuat pengelolaan BUMDes Hanjak Maju ini seyogyanya dilakukan dengan mendorong sinergitas Pemerintah Desa, Badan Permusyawaratan Desa dan masyarakat desa agar mengetahui posisi strategis unit usaha yang dikembangkan oleh BUMDes, sehingga dapat menumbuhkan partisipasi aktif seluruh komponen masyarakat desa.
\end{abstract}

(C) yearThe Authors. Published by Institute for Research and Community Services Universitas Muhammadiyah Palangkaraya. This is Open Access article under the CC-BY-SA License (http://creativecommons.org/licenses/by-sa/4.0/). DOI: https://doi.org/I0.33084/anterior.vxix.xxx.

\section{PENDAHULUAN}

\section{Latar Belakang}

Pemerintah Desa sebagai pelaksana pembangunan dan pemberdayaan masyarakat desa belum bisa leluasa melakukan berbagai kebijakan dalam upaya meningkatkan perekonomian desa, meskipun Pemerintah Pusat telah melaksanakan berbagai program pemberdayaan masyarakat di desa, hasilnya tetap masih belum maksimal.
Undang-Undang Nomor 6 tahun 2014 tentang Desa, terkait dengan pengelolaan Pemerintahan Desa memiliki landasan yang sangat kuat untuk memanfaatkan segala potensi dan sumberdaya yang dimiliki oleh desa untuk sebesarbesarnya kesejahteraan masyarakat desa, bahkan dengan dasar hak rekognisi dan subsidiaritas yang diberikan oleh Negara, desa dapat mendirikan sebuah Badan Usaha yang berbasis ekonomi kerakyatan. 
Badan Usaha Milik Desa atau disingkat dengan BUMDesa yang didirikan oleh desa harus mampu mewadahi serta menampung seluruh kegiatan ekonomi masyarakat desa, sehingga perekonomian desa menjadi kuat, kesejahteraan masyarakat pun meningkat. Sejalan dengan hal itu maka keberadaan BUMDesa sebagai penggerak perekonomian desa mempunyai tujuan menggali potensi-potensi yang ada untuk dapat dijadikan sebagai sumber pemasukan ataupun Pendapatan Asli Desa guna mendukung pembiayaan pembangunan desa melalui Anggaran Pendapatan dan Belanja Desa (APBDes) yang direncanakan oleh Pemerintah Desa setiap tahunnya.

Landasan diatas menunjukkan, kebijakan pengelolaan unit usaha desa (BUMDes) diarahkan untuk pada akhirnya memainkan peran penting dalam menggerakkan roda perekonomiian bagi desa dengan berdasar pada ragam potensi yang dimiliki desa.Sesuai dengan Permendes Nomor 4 Tahun 2015 pasal 3 menyebutkan bahwa tujuan berdirinya BUMDes adalah untuk meningkatkan perekonomian desa, mengoptimalkan manfaat aset, meningkatkan usaha masyarakat dalam pengelolaan potensi ekonomi desa, mengembangkan kerjasama usaha antar desa dan pihak ketiga, menciptakan peluang dan jaringan pasar, membuka lapangan kerja, meningkatkan pendapatan masyarakat desa dan Pendapatan Asli Desa (PADes).

Pendirian BUM Desa Hanjak Maju Kecamatan Kahayan Hilir merupakan salah satu perwujudan komitmen Pemerintah Desa sebagaimana dimaksud di atas dalam rangka menggali segala potensi dan sumber daya perkebunan kelapa sawit yang sudah menjadi mata pencaharian utama sebagian besar masyarakat Desa Hanjak Maju, demi peningkatan perekonomian dan kesejahteraan masyarakat desa.

Namun jika komitmen Pemerintah Desa Hanjak Maju dalam pendirian BUM Desa ini tanpa didukung adanya kemampuan dan pengelolaan yang dilakukan oleh Pengurus BUMDesa secara efektif san efisien, maka yang terjadi upaya untuk mengangkat perekonomian desa terhadap pencapaian kontribusi Pendapatan Asli Desa (PADes) tentu akan sangat sulit dilaksanakan.

Meski penelitian terkait BUMDes sudah banyak dilakukan, namun penelitian ini nantinya akan lebih banyak menyoroti perihal potensi dan pengelolaan BUMDes berkontribusi terhadap pendapatan asli Desa dan berfungsi untuk kebutuhan sosial masyarakat setempat. Disamping itu, penelitian ini ingin melihat sejauh mana keberadaan BUMDes apakah BUMDes didirkan hanya sebagai bentuk kewajiban desa dalam menjalankan regulasi dan program dari Pemerintah Pusat saja atau apakah sebagai upaya memecahkan permasalahan ekonomi di desa sehingga dapat menghasilkan Pendapatan Asli bagi Desa (PADes).

\section{Tujuan Penelitian}

Berdasarkan gambaran permasalahan diatas, tujuan dari penelitian ini adalah

I. Ingin mengetahui sejauh mana pengelolaan BUMDes Hanjak Maju berkontribusi dalam peningkatan Pendapatan Asli Desa

2. Ingin menjawab apakah BUMDes dapat memecahkan permasalahan ekonomi di desa sehingga dapat menghasilkan Pendapatan Asli Desa (PADes).

\section{TINJAUAN PUSTAKA}

\section{Definisi dan Tujuan BUMDes}

Menurut Undang-undang Nomor 6 Tahun 2014 tentang Desa pada pasal I Angka (6), secara rinci menyebutkan bahwa Badan Usaha Milik Desa yang selanjutnya disebut dengan BUMDes, adalah badan usaha yang seluruh atau sebagian besar modalnya dimiliki oleh desa melalui penyertaan secara langsung yang berasal dari kekayaan desa yang dipisahkan guna mengelola aset, jasa pelayanan dan usaha lainnya untuk sebesar- besarnya kesejahteraan masyarakat desa.

BUMDes memiliki tujuan sebagai penggerak roda perekonomian desa. $\mathrm{Hal}$ ini dipertegas berdasarkan Peraturan Menteri Desa, Pembangunan Tertinggal dan Transmigrasi Republik Indonesia Nomor 4 Tahun 2015 tentang Pendirian, Pengurusan dan Pengelolaan, dan Pembubaran Badan Usaha Milik Desa, yaitu BUMDes didirikan dengan tujuan :

a. Meningkatkan perekonomian desa

b. Mengoptimalkan aset desa agar bermanfaat untuk kesejahteraan desa

c. Meningkatkan usaha masyarakat dalam pengelolaan potensi ekonomi desa

d. Mengembangan rencana kerja sama usaha antar desa dan/atau dengan pihak ketiga

e. Menciptakan peluang dan jaringan pasar yang mendukung kebutuhan layanan umum warga

f. Membuka lapangan kerja

g. Meningkatkan kesejahteraan masyarakat melalui perbaikan pelayanan umum, pertumbuhan dan pemerataan ekonomi desa

h. Meningkatkan pendapatan masyarakat dan Pendapatan Asli Desa (PADes)

Dalam pemahaman diatas, maka pengelolaan BUMDes tidak dapat dilakukan secara sentralistik tetapi diserahkan seutuhnya kepada masyarakat.

\section{Pengelolaan dan Penentuan Unit usaha BUMDes}

Peraturan Menteri Dalam Negeri Republik Indonesia Nomor 39 Tahun 2010 tentang BUMDes adalah usaha desa yang dibentuk/didirikan oleh Pemerintah Desa yang kepemilikan modal dan pengelolaannya dilakukan oleh pemerintah desa dan masyarakat. Badan Usaha Milik Desa (BUMDes) 
adalah lembaga usaha desa yang dikelola oleh masyarakat dan pemerintah desa dalam upaya memperkuat perekonomian desa dan dibentuk berdasarkan kebutuhan dan potensi desa.

Badan Usaha Milik Desa (BUMDes) merupakan sebuah lembaga yang dibentuk dan dirikan oleh pemerintah desa yang kepemilikan modal dan pengelolaannya dilakukan oleh pemerintah desa dan masyarakat (Ramadana et al 20l3). BUMDes merupakan pilar perekonomian desa yang berfungsi sebagai lembaga sosial (social institution) dan komersial (commercial institution) yang berpihak pada kepentingan masyarakat serta mencari keuntungan (Meirinawati dan Dewi 20l3).

Sebagai suatu lembaga ekonomi lokal, BUMDes memiliki aturan pengelolaan dalam mengatur lembaga tersebut. Unsur Manajemen pada BUMDes terdiri dari: (a) manusia yang memiliki potensi, energy, atau disebut sumberdaya manusia, (b) money, mencakup uang yang dikelola, yaitu sumber dana yang dikelola badan usaha, (c) material, bahan baku serta sarana dan prasarana untuk produksi, (d) method, mencakup teknik dan prosedur yang harus ditempuh dalam rangka menciptakan barang dan jasa, (e) market, pasar sebagai tempat penyaluran produk dan jasa. Prinsip BUMDes meliputi kooperatif, partisipatif, demokrasi, transparansi, emansipatif, akuntabel, dan sustainable (Gunawan 20II).

Dalam hal penentuan jenis usaha BUMDes maka yang perlu diperhatikan adalah ragam potensi dan kebutuhan masyarakat setempat dalam rangka memberikan layanan umum kepada masyarakat. Dalam Permendesa PDTT Nomor 4 Tahun 2015 tentang Pendirian Pengurusan dan Pengelolaan, dan Pembubaran Badan Usaha Milik Desa, Pemerintah Pusat sebenarnya telah memberikan pedoman mengenai penentuan jenis usaha desa. Melalui peraturan ini diharapkan desa dapat memanfaatkan momentum penting dalam membangun desanya masing-masing. Adapun klasifikasi jenis usaha desa ini terdiri dari :

a. Bisinis Sosial (Social Business) sederhana yang memberikan pelayanan umum (serving) kepada masyarakat dengan memperoleh keuntungan finansial. jenis usaha ini dapat memanfaatkan sumber daya lokal dan teknologi tepat guna, meliputi air minum desa, usaha listrik desa, lumbung pangan dan sumber daya lokal dan teknologi tepat guna lainnya.

b. Bisnis Penyewaan (Renting)barang untuk melayani kebutuhan masyarakat Desa dan ditujukan untuk memperoleh Pendapatan Asli Desa, meliputi penyewaan atas alat transportasi, perkakas pesta, gedung pertemuan, rumah toko, tanaj milik BUM Desa dan barang sewaan lainnya c. Bisnis yang Berpoduksi dan/atau Berdanag (Trading) barang-barang teretntu untuk memenuhi kebutuhan masyarakat maupun dipasarkan pada skala pasar yang lebih luas, meliputi:pabrik es, pabrik asap cair, hasil pertanian, sarana produksi pertanian, sumur bekas tambang dan kegiatan bisnis produktif lainnya.

d. Bisnis Keuangan (Financial Business)yang memenuhi kebutuhan usaha-usaha skala mikro yang dijalankan oleh pelaku usaha ekonomi Desa dengan memberikan akses kredit dan peminjaman yang mudah diakses oleh masyarakat Desa.

e. Usaha Bersama (Holding) sebagai indukdari unit-unit usaha yang dikembangkan masyarakat Desa bik dalam skala lokal desa maupun kawasan perdesaan. Kegiatan usaha bersama ini meliputi pengembangan kapal desa berskala besar untuk mengorganisasi nalayan kecil agar usahanya menjadi lebih ekspansif, desa wisata yang mengorganisir rangkaian jenis usaha dari kelompok masyarakat dan kegiatan usaha bersama yang mengkonsolidasikan jensi usaha lokal lainnya.

Kinerja tidak hanya dipengaruhi oleh sejumlah usaha yang dilakukan oleh seseorang/ badan usaha, tetapi dipengaruhi pula oleh kemampuannya, seperti : pengetahuan, pekerjaan, keahlian serta bagaimana seseorang merasakan peran yang dibawakan (Juliansyah Noor, 2013). Salah satu faktor kunci kesuksesan BUMDes adalah manajemen yang rapi dengan kinerja per bagian antara Penasihat yang dijabat secara ex officio oleh Kepala Desa, Pelaksana Operasional dan Pengawas BUM Desa yang dapat dipertanggungjawabkan (Rudy Suryanto 2018).

Demikian juga dalam hal strategi penentuan posisi harga beli atau harga jual ketika seorang pesaing menaikkan/ menurunkan harga produk dalam pasar homogen, perusahaan lain tidak harus menyesuaikan dengannya. Mereka akan mengikuti jika peningkatan/ penurunan harga tersebut bermanfaat bagi produksi maupun industri secara keseluruhan (Thamrin Abdullah dan Francis Tantri, 20l4). Oleh karena itu, Manajemen modal kerja sangat dibutuhkan suatu perusahaan terutama untuk beberapa alasan. Modal kerja yang terlalu besar dari kebutuhan nyata akan mengakibatkan tidak efisiennya penggunaan dana perusahaan. Sebaliknya bila modal kerjanya terlalu kecil, juga akan menganggu jalannya operasi perusahaan. Fungsi pengaturan atau manajemen yang akan menjaga agar jumlah modal kerja di perusahaan sesuai dengan kebutuhan (Moh. Benny Alexandri, 2009)

Namun dalam beberapa kondisi tertentu jika Badan Usaha ingin tetap menjaga ratio kecukupan modal guna memperlacar bisnisnya, maka perlu ada pertimbangan bisnis untuk meningkatkan kapasitas permodalan dengan cara meminjam kepada pihak perbankan. Pinjaman modal sebenarnya dapat 
diperoleh dari berbagai pihak, baik lembaga keuangan yang bersifat komersil, maupun lembaga non keuangan yang bersifat sosial. Untuk itu, ada 2 hal yang harus dipegang badan usaha agar mendapatkan pinjaman modal : (I) Pahami pola pikir lembaga pemberi pinjaman modal, (2) Ikuti syarat dan ketentuan lembaga pemberi pinjaman modal (Ganjar Isnawan, 20I I).

\section{Pendapatan Asli Desa (PADesa)}

Menurut Undang-undang Nomor 6 Tahun 2014 tentang Desa, Pendapatan Asli Desa (PADes) merupakan pendapatan yang berskala dari kewenangan Desa berdasarkan hak asal usul dan kewenangan skala lokal desa. Pendapatan Asli Desa terdiri dari hasil usaha, hasil aset, swadaya dan partisipasi, gotong royong dan lain-lain pendapatan asli desa. (David Wijaya, 2017)

a. Hasil Usaha, misalnya hasil BUMDes dan tanah kas desa. Sumber pendapatan lain yang dapat diusahakan dari desa antara lain berasal dari BUMDes, pengelolaan pasar desa, pengelolaan kawasan wisata skala desa, pengelolaan tambang mineral non logal dan tambang batuan dengan tidak menggunakan alat berat, serta sumber lainnya dan tidak untuk diperjuabelikan.

b. Hasil aset, misalnya tambatan perahu, pasar desa, tempat pemandian umum, serta jaringan irigasi.

c. Swadaya, Partisipasi, dan Gotong royong, misalnya membangun dengan kekuatan sendiri yang melibatkan peran serta masyarakat berupa tenaga dan barang yang dinilai dengan uang

d. Lain-lain Pendapatan Asli Desa, misalnya hasil pungutan desa

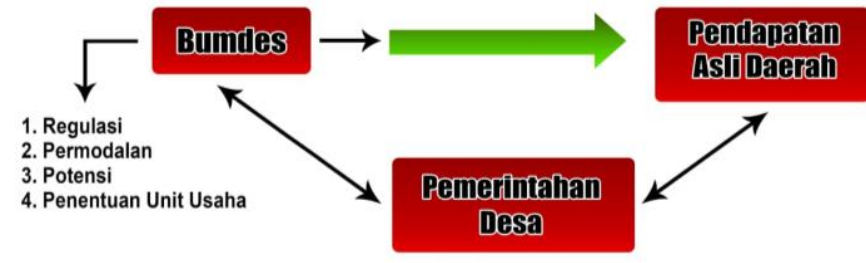

\section{METODE PENELITIAN}

Penelitian ini bertujuan untuk memahami secara lebih mendalam tentang bagaimana telaah potensi dan pengelolaan BUMDes yang berkontribusi terhadap Pendapatan Asli Desa (PADes) dalam menentukan skema Anggaran Pendapatan dan Belanja Desa yang sering disebut dengan istilah APB Desa.

Untuk mencapai tujuan tersebut, penelitian ini menggunakan pendekatan kualitatif yang berupaya menghasilkan data deskripsi berupa kata-kata tertulis atau lisan dari orang-orang dan perilaku yang dapat diamati. Melalui penelitian deskriptif, akan dihasilkan suatu gambaran yang lebih detail mengenai fenomena sosial dari suatu subyek atau tipe dari orang-orang dan kegiatan sosial tertentu.

\section{HASIL PENELITIAN DAN PEMBAHASAN}

\section{PENGELOLAAN BUMDES}

Sistem pengelolaan unit usaha yang dijalankan oleh Pengurus BUMDes Hanjak Maju sesuai AD/ART tetap mengedepankan azas kegotongroyongan dan kekeluargaan, sehingga prinsif profesionalisme murni sebagai badan usaha sekaligus lembaga ekonomi desaa belum dapat diterarpkan sepenuhnya, mengingat BUMDes hadir untuk menjalankan dua fungsi, yaitu fungsi sosial dan fungsi komersial, artinya aktivitas BUMDes tidak hanya mementingkan bisnis dan profit semata tapi juga harus memperhatikan aspek sosial dan benefit bagi kepentingan masyarakat desa.

Sejak awal prinsip-prinsip dasar tersebut sudah dilakukan oleh BUMDes Hanjak Maju, dimana setiap produk yang diperjualbelikan oleh masing-masing unit usaha selalu mempertimbangkan aspek harga jual maupun harga beli agar dapat terjangkau dan menguntungkan serta melindungi hak-hak masyarakat desa sebagai produsen sekaligus konsumen.

Namun di sisi lain, ada beberapa faktor yang menjadi kendala BUMDes Hanjak Maju dalam penentuan harga produk baik itu TBS kelapa sawit, gas $3 \mathrm{~kg}$ maupun pupuk, yaitu sebagai penyalur tentu BUMDes juga sangat bergantung pada fluktuasi harga yang ditetapkan oleh pabrik kelapa sawit, agen gas $3 \mathrm{~kg}$ maupun pupuk bersubsidi.

Disamping itu ketersediaan atau stok barang di tingkat agen/ pangkalan yang tidak menentu juga turut mempengaruhi kelancaran usaha BUMDes Hanjak Maju, serta adanya sistem sortir buah yang diterapkan oleh pihak pabrik kepada semua penyuplai TBS termasuk BUMDes Hanjak Maju.

Padahal BUMDes Hanjak Maju tidak memiliki karyawan yang terampil dan memahami teknik proses penyortiran TBS yang dibeli dari petani kelapa sawit Desa Hanjak Maju, sehingga hal ini sangat mempengaruhi besar kecilnya biaya operasional BUMDes.

Namun dari sisi usaha, khususnya jual beli TBS kelapa sawit, BUMDes Hanjak Maju sering menghadapi persaingan yang tidak dapat dihindari dengan para pengepul dari luar desa yang menerapkan sistem permainan harga beli TBS di tingkat petani, dimana para pengepul lebih berani membeli harga TBS di atas dari harga yang ditetapkan oleh BUMDes Hanjak Maju.

Ketika seorang pesaing menaikkan/ menurunkan harga produk dalam pasar homogen, perusahaan lain tidak harus menyesuaikan dengannya. Mereka akan mengikuti jika peningkatan/ penurunan harga tersebut bermanfaat bagi produksi maupun industri secara keseluruhan (Thamrin Abdullah dan Francis Tantri, 20l4).

Walaupun para petani lebih banyak memilih menjual hasil panen TBS kelapa sawitnya kepada pengepul dari luar desa, BUMDes Hanjak Maju tidak perlu melakukan tindakan spekalutif yang dapat mengakibatkan 
kerugian bagi BUMDes, karena sistem grading yang diterapkan oleh pabrik kelapa sawit terhadap TBS yang dibeli dari pihak luar sering tidak sesuai dengan sistem grading yang dilakukan oleh BUMDes terhadap TBS yang dibeli dari masyarakat petani sawit Desa Hanjak Maju.

Kondisi ini tentunya menjadi salah satu kendala besar bagi pengelolaan BUMDes Hanjak Maju, belum lagi sistem pembayaran TBS yang dilakukan oleh Pabrik Kelapa Sawit PT. Graha Inti Jaya setiap NI bulan sekali, mengakibatkan perputaran modal BUMDes Hanjak Maju sering terhenti dan hanya bisa membeli hasil panen TBS petani berikutnya dengan cara kredit.

Manajemen modal kerja sangat dibutuhkan suatu perusahaan terutama untuk beberapa alasan. Modal kerja yang terlalu besar dari kebutuhan nyata akan mengakibatkan tidak efisiennya penggunaan dana perusahaan. Sebaliknya bila modal kerjanya terlalu kecil, juga akan menganggu jalannya operasi perusahaan. Fungsi pengaturan atau manajemen yang akan menjaga agar jumlah modal kerja di perusahaan sesuai dengan kebutuhan (Moh. Benny Alexandri, 2009)

Untuk menyiasati keterbatasan dana tersebut, BUMDes Hanjak Maju berusaha memberikan pemahaman kepada petani TBS bahwa usaha yang dilakukan oleh BUMDes Hanjak Maju adalah untuk kepentingan masyarakat desa, sehingga solusinya BUMDes Hanjak Maju menggunakan dana talangan dari unit usaha lain.

Ternyata bukan hanya sampai disitu saja kendala yang dihadapi oleh BUMDes Hanjak Maju, selama ini pihak Pabrik Kelapa Sawit PT.Graha Inti Jaya belum menjadikan BUMDes Hanjak Maju sebagai mitra atau rekanan langsung karena tidak memiliki kontrak kerja dalam bentuk SPK.

Adapun persyaratan yang harus dipenuhi oleh pihak rekanan untuk mendapat SPK dengan Pabrik Kelapa Sawit PT. Graha Inti Jaya adalah harus sanggup menyuplai TBS Kelapa Sawit sebanyak 100 Ton dalam masa satu bulan.

Hal inilah yang masih belum bisa dipenuhi oleh BUMDes Hanjak Maju, karena alasan keterbatasan modal kerja, karena dengan kapasitas produksi 100 Ton per bulan maka paling tidak BUMDes Hanjak Maju harus mempersiapkan modal kerja sebanyak 2-3 kali lipat dari jumlah kapasitas pasokan TBS ke Pabrik PT. Graha Inti Jaya, mengingat interval waktu pembayaran dilakukan selama satu bulan sekali.

Akhirnya, BUM Desa Hanjak Maju mau tidak mau harus memilih bergabung dengan salah satu rekanan pabrik pemegang SPK, hal inilah yang membuat BUMDes Hanjak Maju sangat tergantung dengan pihak lain, baik dari pencatatan penjualan TBS maupun sistem pembayaran.

Kekurangan dan keterbatasan pengelolaan usaha BUMDes Hanjak Maju ini membuat perkembangannya sampai dengan saat ini belum dapat terpecahkan secara utuh, padahal potensi yang sedemikian besar seharusnya dapat memberikan kontribusi bagi Pendapatan Asli Desa (PADes) secara maksimal.

Bertolak dari latar belakang permasalahan tersebut, BUMDes Hanjak Maju sudah berupaya melakukan perubahan dengan memperhatikan berbagai aspek baik eksternal maupun internal, salah satu satunya dengan memperluas jaringan pemasaran TBS ke pabrik-pabrik kelapa sawit lain dengan tujuan untuk mendapat harga beli TBS yang lebih variatif, kompetitif dengan jangka waktu pembayaran lebih pendek dan fleksibel, supaya lebih menguntungkan untuk BUMDes Hanjak Maju.

Meskipun hasilnya belum maksimal, dikarenakan pabrik-pabrik tersebut jaraknya relatif jauh dibandingkan dengan lokasi Pabrik PT. Graha Inti Jaya, bahkan pencairan dananya pun lebih lambat, namun BUMDes Hanjak Maju tetap mepertahankan strategi untuk bergabung dengan SPK orang lain.

Selanjutnya BUMDes Hanjak Maju masih mencoba memperkuat akses permodalan BUMDes melalui kerjasama dengan pihak perbankan yang ada di Kabupaten Pulang Pisau, seperti Bank BNI maupun Bank BRI, dimana Bank-Bank Pemerintah tersebut telah melakukan MoU dengan Kementerian Desa Pembangunan Daerah Tertinggal dan Transmigrasi, dalam rangka mengembangkan BUM Desa yang ada di seluruh Indonesia.

Kemitraan antara BUMDesa dengan pihak perbankan jelas akan sangat menguntungkan, karena melalui kegiatan ekonomi produktif yang tercipta di desa, maka akan memberikan impact yang luas bagi perekonomian di desa.

Pinjaman modal sebenarnya dapat diperoleh dari berbagai pihak, baik lembaga keuangan yang bersifat komersil, maupun lembaga non keuangan yang bersifat sosial. Untuk itu, ada 2 hal yang harus dipegang badan usaha agar mendapatkan pinjaman modal: (I) Pahami pola pikir lembaga pemberi pinjaman modal, (2) Ikuti syarat dan ketentuan lembaga pemberi pinjaman modal (Ganjar Isnawan, 20 I I).

Namun, jika kemitraan antara BUMDes dan Perbankan dapat dibangun, maka perhitungan keuangan dari perdagangan TBS kelapa sawit oleh BUMDes Hanjak Maju berdasarkan kapasitas produksi TBS dalam sebulan mencapai 100 Ton dengan harga beli TBS/ kg sebesar Rp, I.000,- maka nilai uang yang diterima oleh petani sawit bisa mencapai Rp. I00 Juta atau Rp I,2 Milyar dalam setahun.

Ini artinya, peredaran dan perputaran uang di Desa Hanjak Maju sungguh sangat luar biasa, pendapatan serta daya beli masyarakat desa menjadi kuat, perekonomian desa pun meningkat.

Dengan kuatnya perekonomian masyarakat desa dari hasil perkebunan kelapa sawit, maka akan berkontribusi terhadap Pendapatan Asli Desa (PADes), dimana sebagian keuntungan usaha BUM Desa akan diserahkan kepada Pemerintah Desa untuk dijadikan sebagai salah satu sumber pendanaan Anggaran Pendapatan dan Belanja Desa (APBDes) bagi pembangunan dan pemberdayaan masyarakat desa.

Jumlah Penerimaan PADes Hanjak Maju dengan rata-rata produksi TBS per bulan sebesar 100 Ton maka dalam setahun total produksi TBS Desa Hanjak Maju mencapai I.200 Ton dengan netto margin per kilogram sebesar Rp 100,- maka keuntungan yang diperoleh BUMDes Hanjak Maju selama satu tahun mencapai Rp I 20 Juta.

Jika keuntungan bersih yang diterima oleh BUMDes Hanjak Maju sebesar Rp 120 Juta, maka pembagian 
keuntungan BUMDes yang dialokasikan sebagai PADes Hanjak Maju berdasarkan Perdes Nomor 4 Tahun 2016 tentang BUMDes Hanjak Maju sebesar 20 persen, sejumlah Rp 24.000.000,-

Adapun unit usaha jual beli Gas LPG $3 \mathrm{Kg}$ belum bisa dimaksimalkan karena BUM Desa Hanjak Maju belum dapat menstabilkan stok atau persediaan LPG, mengingat selama ini BUMDes Hanjak Maju bukan merupakan Pangkalan LPG yang secara berkala mendapat pasokan dari Agen LPG.

Pengajuan permohonan yang sedang diajukan oleh Dinas Perindustrian dan Perdagangan Kabupaten Pulang Pisau kepada pihak Pertamina masih sangat terbatas, dimana kuota BUMDes yang akan dijadikan sebagai Pangkalan LPG sebanyak 5 Desa, tidak termasuk BUMDes Hanjak Maju dikarenakan di Kecamatan Kahayan Hilir sudah banyak berdiri Pangkalan LPG.

Setali tiga uang dengan Unit jual beli gas LPG, unit usaha jual beli sarana produksi/ saprodi pertanian yang memperdagangkan pupuk bersubsidi kepada petani kelapa sawit juga belum mendapat dukungan dari pihak pangkalan dan agen pupuk, sehingga sering terjadi kekosongan stok/ persediaan pupuk oleh BUMDes Hanjak Maju.

Dari keseluruhan permasalahan di atas, maka secara tidak langsung dampak yang dirasakan oleh BUMDes Hanjak Maju adalah terjadinya perlambatan perputaran (turn over) produk/barang yang diperjualbelikan, akibatnya kinerja dan produktivitas pada masing-masing unit usaha di BUMDes Hanjak Maju akan terganggu. Dalam jangka panjang, tingkat kepercayaan masyarakat terhadap keberadaan dan kemampuan BUMDes Hanjak Maju sebagai lembaga ekonomi desa pun akan menurun.

Kinerja tidak hanya dipengaruhi oleh sejumlah usaha yang dilakukan oleh seseorang/ badan usaha, tetapi dipengaruhi pula oleh kemampuannya, seperti: pengetahuan, pekerjaan, keahlian serta bagaimana seseorang merasakan peran yang dibawakan (Juliansyah Noor, 2013).

Untuk itu maka Pemerintah Desa Hanjak Maju harus memprioritaskan kegiatan BUMDes Hanjak Maju sebagai upaya pemberdayaan ekonomi masyarakat desa dengan memperkuat pengelolaan BUMDes. Segala potensi yang dimiliki desa agar dapat didayagunakan sepenuhnya bagi kepentingan masyarakat, sebagaimana disebutkan dalam Peraturan Menteri Desa Pembangunan Daerah Tertinggal dan Transmigrasi Nomor 19 Tahun 2017 tentang Penetapan Prioritas Penggunaan Dana Desa Tahun 2018.

Upaya memperkuat pengelolaan BUMDes Hanjak Maju ini seyogyanya dilakukan dengan mendorong sinergitas Pemerintah Desa, Badan Permusyawaratan Desa (BPD) dan masyarakat desa agar mengetahui posisi strategis unit usaha (bisnis) yang dikembangkan oleh BUMDes, sehingga dapat menumbuhkan partisipasi aktif seluruh komponen masyarakat desa.

Karena tanpa adanya dukungan dan partisipasi masyarakat desa, maka pengembangan usaha BUMDes Hanjak Maju tidak dapat dijalankan secara maksimal, sebagaimana dalam perjalanannya BUMDes didirikan berdasarkan kesepakatan masyarakat yang dituangkan dalam sistem perencanaan desa melalui Musyawarah Desa (Musdes) Pendirian BUMDes.

Adapun kesepakatan yang dihasilkan dalam Musdes Pendirian BUMDes Hanjak Maju, terdiri dari Peraturan Desa tentang Pendirian BUMDes, AD/ART, Pengurus Organisasi Pengelola BUMDes serta Kebijakan Modal Awal dan Penyertaan Modal Desa pada BUMDes, selanjutnya berdasarkan kesepakatan tersebut maka Desa Hanjak Maju mempunyai beberapa ketetapan tentang :

I) Peraturan Desa tentang Pendirian BUMDes Hanjak Maju

2) Anggaran Dasar / Anggaran Rumah Tangga (AD/ART)

3) SK Kepala Desa tentang Susunan Pengurus Organisasi Pengelola BUMDes Hanjak Maju.

Setiap pengelola BUMDes Hanjak Maju wajib melaksanakan semua kegiatan operasional berdasarkan Perdes, AD/ART dan Keputusan Kepala Desa sebagai pedoman pelaksanaan usaha BUMDes.

Salah satu faktor kunci kesuksesan BUMDes adalah manajemen yang rapi dengan kinerja per bagian antara Penasihat yang dijabat secara ex officio oleh Kepala Desa, Pelaksana Operasional dan Pengawas BUM Desa yang dapat dipertanggungjawabkan (Rudy Suryanto 2018).

Dalam tata kelola BUMDes, pelaksana operasional bukan satu-satunya pihak yang bertanggungjawab terhadap keberhasilan BUMDes, akan tetapi masih ada Kepala Desa dan Pengawas BUMDes yang dapat mensinergikan tugas dan fungsinya masing-masing menjadi kekuatan besar BUMDes. Ada 4 faktor yang harus diperhatikan dalam tata kelola BUM Desa, antara lain : (I) Kelembagaan, mencakup Penasihat, Pengelola dan Pengawas harus dapat memahami dan melalukan tata kelola BUM Desa yang baik, dengan membuat : (a) Job Description (Daftar Pekerjaan), (b) Rancangan sistem koordinasi, (c) Pedoman Kerja Organisasi, (d) Desain Sistem Informasi, (e) Rencana Bisnis (Bussines Plan), (f) Sistem Administrasi dan Pembukuan dan (g) Legalitas Hukum Unit Usaha. (2) Pedoman, Kebijakan dan SOP BUM Desa, meliputi : (a) Masa Jabatan Pengelola BUM Desa, (b) Penggajian Pengelola BUM Desa. (3) Keuangan BUM Desa, (a) Anggaran Keuangan BUM Desa, (b) Pencatatan Keuangan BUM Desa. (4) Evaluasi Kinerja dan Akuntabilitas BUM Desa, berupa (a) Laporan Pertanggungjawaban BUM Desa, (b) Mengevaluasi Kinerja Ketua BUM Desa, (c) Laporan Keuangan BUM Desa. (5) Menakar Kesehatan BUM Desa, menggunakan (a) Analisis kesehatan keuangan BUM Desa, (b) Analisis manajemen BUMDes, (c) Analisis hubungan antara Penasihat, Pengelola dan Pengawas BUM Desa, (d) Analisis Model Bisnis BUM Desa, (d) Analisis Pasar.

Apabila dilakukan evaluasi terhadap BUMDes dan hasil ternyata tidak sehat, maka para pengelola BUMDes benar-benar perlu menyadari dimana poin yang salah, agar dapat dilakukan perbaikan.

Selanjutnya, jika tingkat kesalahan yang telah dilakukan oleh Pengelola BUMDes sudah sangat sistematis dan parah, maka sebaiknya mengembalikan keadaan 
BUMDes pada proses awalnya daripada keadaan BUMDes semakin memburuk.

\section{SIMPULAN}

Berdasarkan hasil penelitian maka diperoleh kesimpulan sebagai berikut :

I. Pengelolaan BUMDes Hanjak Maju dengan memperkuat kelembagaan serta ratio kecukupan modal dapat meningkatkan produktivitas maupun kinerja BUMDes

2. Meningkatkan sinergitas dan partisipasi aktif Penasihat, Pengelola, Pengawas BUMDes Hanjak Maju serta seluruh komponen masyarakat menjadi faktor pendorong kemajuan BUMDes.

3. Memperluas jaringan penyedia / pemasok Gas LPG 3 kg maupun Pupuk bersubsidi dapat menjamin stabilitas persedian gas dan pupuk.

4. Pengelolaan dan manajemen yang baik akan memperkuat bisnis BUMDes Hanjak Maju secara kompetitif, sehingga keuntungan usaha BUMDes Hanjak Maju berpotensi dalam memberikan kontribusi Pendapatan Asli Desa (PADes).

\section{REKOMENDASI}

Untuk rekomendasi dalam penelitian ini, bahwa manajemen atau pengelolaan BUMDes Hanjak Maju harus terus ditingkatkan dengan memberikan penguatan kapasitas kepada Pengelola BUMDes Hanjak Maju, agar dapat menerapkan sistem manajemen dalam setiap menganalisa masalah, misalnya menggunakan analisa SWOT, Analisa CSF (Critical Succsess Factor), maupun kajian lainnya.

BUMDes Hanjak Maju harus memperkuat penguasaan terhadap sistem grading TBS yang diberlakukan oleh Pabrik Kelapa Sawit untuk diterapkan oleh BUMDes pada proses pembelian (purchasing) TBS dari petani sawit Desa Hanjak Maju..

BUMDes Hanjak Maju harus membuat terobosan dan inovasi baru dengan menggandeng BUMDes-BUMDes tetangga untuk berkolaborasi dengan membentuk BUMADes (BUMDes Antar Desa), agar produktivitas dan kinerja BUMDes Hanjak Maju semakin kuat menghadapi Kompetitor dan Predator bisnis dari luar desa.

Mencari formulasi strategi pengelolaan yang sesuai dengan kondisi BUMDes Hanjak Maju melalui Asosiasi BUMDes Kalimantan Tengah (ASBUMDES), untuk mendapatkan bantuan konsultasi dan fasilitasi dalam pengembangan pengelolaan usaha BUMDes.

\section{DAFTAR PUSTAKA}

Creswell, J.W, 2013. Reseacrh Design Pendekatan Kualitatif, Kuantitatif, dan Mixed, edisi ketiga, Pustaka Pelajar. Yogyakarta

Wijaya, David. 2017. Akuntasi Desa. Gava Media. Yogyakarta
Gunawan K. 20II. Manajemen Bumdes Dalam Rangka Menekan Laju Urbanisasi. Jurnal Sains dan Teknologi Vol. 10. 3.

Milles dan Hubberman, 1992. Analisis Data Kualitatif. Rineka Cifta : Jakarta

Benny Alexandri, Moh, 2009, Manajemen Keuangan Bisnis, Alfabeta : Bandung

Isnawan, Ganjar, 20I I. Cara Instan Mendapatkan Pinjaman Modal. Agogos Publishing, Jakarta Barat

Noor, Juliansyah, 2013. Penelitian Ilmu Manajemen, Tinjauan Filosofis dan Praktis. Kencana Prenada Media Group, Jakarta

Abdullah, Thamrin dan Tantri, Francis, 2014. Manajemen Pemasaran. PT. RajaGrafindo Persada, Jakarta

Suryanto, Rudy, 2018. Peta Jalan BUMDes Sukses. PT. Syncore Indonesia, Yogyakarta

\section{Peraturan}

Undang- Undang Republik Indonesia No 6 Tahun 2014 tentang Desa

Undang-Undang Republik Indonesia No 23 Tahun 2014 tentang Pemerintah Daerah

Peraturan Pemerintah Republik Indonesia Nomor 72 Tahun 2005 tentang Desa

Peraturan Pemerintah Republik Indonesia Nomor 43 Tahun 2014 tentang Peraturan Pelaksanaan UU Nomor 6 Tahun 2014 tentang Desa

Peraturan Menteri Dalam Negeri Republik Indonesia Nomor 39 Tahun 2010 tentang Badan Usaha Milik Desa

Peraturan Menteri Desa Pembangunan Daerah Tertinggal dan Transmigrasi Republik Indonesia Nomor 4 Tahun 2015 tentang Pendirian, Pengurusan dan Pengelolaan, dan Pembubaran Badan Usaha Milik Desa.

Peraturan Menteri Dalam Negeri Republik Indonesia Nomor II4 Tahun 2014 tentan Pedoman Pembangunan Desa

Peraturan Menteri Desa Pembangunan Daerah Tertinggal dan Transmigrasi Republik Indonesia Nomor 19 Tahun 2017 tentang Penetapan Prioritas Penggunaan Dana Desa Tahun 2018 